But the observation that initial hybrids are less aggressive and apparently unable to benefit immediately from such inheritance is not of much importance to agriculturalists. What is important is the evolutionary potential for transgenic crop genes to be shifted and shuffled around in a way that may eventually result in a novel modified gene complex.

Just as Clark Kent was able to change into Superman - as your News story put it - such a novel complex, initially born an inferior weakling, may very well have a chance of becoming a 'superweed'.

Norris Muth

Department of Ecology and Evolutionary Biology,

University of Tennessee, Knoxville, Tennessee

37996-1610, USA

\section{Venezuelan government is backing science}

Sir-Mendoza et al. in Correspondence (Nature 421, 473; 2003) ask for help in the name of the Venezuelan scientific community, in view of the current turmoil in our country. However, as we show here, the real figures tell a different story, pointing to the efforts made by the current government, which has been in power since 1999, to satisfy the demands of the scientific sector.

More than $60 \%$ of Venezuela's science budget comes from the government. During the past ten years, total investment has continuously increased, from US $\$ 177$ million in 1990 to $\$ 405$ million during 2000. In 2001, the state science budget was, astonishingly, increased by more than 50\%, reaching $\$ 637$ million. As a consequence there have been more grants for established researchers, as well as a significant improvement in economic support for graduate students.

Notably, Venezuela spends more on science and technology activities per researcher than any other country in North or South America apart from the North American Free Trade Agreement (NAFTA) countries: Canada, Mexico and the United States. In 1999, while the NAFTA countries spent $\$ 126,000$ per researcher, Venezuela spent $\$ 76,000$, compared with an average expenditure of just $\$ 62,000$ per researcher in the countries of Latin America and the Caribbean region. In 2000 Venezuela's spending increased to $\$ 86,000$ per researcher, while the average in Latin America and the Caribbean went down to $\$ 61,000$ (see www.ricyt.edu.ar).

The current government has created a Ministry of Science and Technology and approved the first law promoting science and technology in our country's history.
Regional governments are now required to contribute part of their budgets to science, and a considerable amount of money has been devoted to regional programmes. We believe that the present government has provided benefits to the scientific community, and that its significant efforts for the advancement of science in Venezuela should be recognized.

A considerable number of enthusiastic science students and other young scientists in Venezuela have shown their dedication to science during the current social and political conflict, in particular during December and January, when many of them kept working despite transport difficulties caused by petrol shortages and illegal road blocks.

Despite the efforts made by some political and economic sectors to destabilize the democratically elected government, many members of the scientific community are confident that Venezuelan science will overcome this adverse situation in the near future.

Undoubtedly, though, the current crisis will have a negative effect on this year's science budget (see "Venezuelan science hit by national strikes", www. scidev.net, 7 February 2003).

Juan Luis Cabrera ${ }^{\star}$, Luis Emilio Guerrero $\dagger$, Arnaldo Donoso*

${ }^{*}$ Centro de Física, Instituto Venezolano de Investigaciones Científicas, Apartado 21827, Caracas 1020-A, Venezuela

$\dagger$ Departamento de Física, Universidad

Simón Bolivar, Apartado 89000,

Caracas 1080-A, Venezuela

Other signatories to this letter can be found at

http://caos.fs. usb.ve/carta.html

\section{Free access to publicly funded databases is vital}

Sir - The International Society for Computational Biology (www.iscb.org) wishes to express regret and concern about the decision by the US Department of Energy (DOE) to shut down the PubScience web site (see Nature 411, 980; 2001 and 418, 805; 2002). Unfortunately this decision came to our attention too late to comment before the DOE's official deadline passed.

Free access to scientific knowledge and data is essential to scientific progress. Free access to publicly funded databases such as PubScience, PubMed, Medline and GenBank reflects the public's role in funding the science that led to these data, and provides a cost-effective means for disseminating information to the scientific community. It is essential to future progress in scientific research that these public information resources remain freely accessible. Philip E. Bourne

President, International Society for Computational Biology, San Diego Supercomputer Center, University of California, San Diego, 9500 Gilman Drive, La Jolla, California 92093-0505, USA

\section{GreenSea's interest in fertilizing sea with iron}

Sir-Your News feature "The oresmen" (Nature 421, 109-110; 2003) characterizes the objectives of GreenSea Venture as strongly in favour of episodic iron fertilization of selected high-nutrientlow-chlorophyll ocean areas, a nonpolluting and inexpensive technique. In fact, we believe only that this may be an efficacious approach to controlling the concentration of carbon dioxide in the atmosphere.

Our activities are in support of 'sound science' and the further development of knowledge applicable to iron fertilization as a carbon-control technology. Only with such knowledge can policy-makers determine whether this technology should be developed, together with other approaches, for efforts at climate control. M. Lee Rice

GreenSea Venture, Inc., 20150 Woodtrail Road, Round Hill, Virginia 20141-1943, USA

\section{Eastern Europe nurtures talent for the West}

Sir - As a scientist from Slovakia, one of the Eastern European countries in the process of joining the European Union, I was pleased to see your Opinion article "Too quiet on the Eastern front" discussing science in Eastern Europe (Nature 421, 459; 2003).

After spending five years doing my $\mathrm{PhD}$ in Austria and two more years as a postdoc in England, I was interested in returning to Slovakia to pursue my scientific career there. I was kindly offered a university position with the possibility of starting my own group - but the salary was only SKK100,000-200,000 $(\$ 2,550-\$ 5,100)$ a year. Because I have two children I had no choice but to look for other options.

I have realised that, unfortunately, there are no fellowships that would allow me to go back to Slovakia. The situation is similar in all Eastern European countries: universities nurture talents for the Western countries.

Juraj Gregan

Department of Zoology, University of Oxford, South Parks Road, Oxford OX1 3PS, UK 